\title{
Good Governance as an Instauration Towards Socioeconomic Development: A Case Study of Pakistan
}

\author{
Shama Zaman (Lead Author) \\ Department of Political Science, Department of Agriculture \& Agribusiness \\ Management, University of Karachi, Pakistan. \\ E-mail: schamazaman@gmail.com \\ Samina Saeed \\ Department of Political Science, University of Karachi, Pakistan.
}

Received: June 10, 2019 Accepted: July 8, 2019 Online published: July 29, 2019

doi:10.5296/jpag.v9i3.15168ＵRL: https://doi.org/10.5296/jpag.v9i3.15168

\begin{abstract}
Good governance has been inclinational to a well-civilized society. The notion of governance has emphatically been promoted in the twenty-first century for sustainable socioeconomic development in a form of millennium \& sustainable development goals (MDGs and SDGs). Because good governance is one of the multilayered stratagem being directly involved in a socioeconomic progression, it sets off a mechanism of modus operandi from higher to lower governing hierarchy. Significantly, it enlightens basic democratic system to levitate an infrastructure of good governance through standing on multidimensional pillars of accountability, transparency, rule of law and mass participation. Strategic planning of good governance overcomes the uneven justifications in all spheres of life. In fact, justified distribution of socioeconomic assets is deployed by the principles of good governance. That assists in maintaining the balance of power to not only initiate the development but cause its sustainability in the course of socioeconomic paradigms. Thus it is subsumed directly or indirectly in strengthening the individual, institutional, and societal capacity development. Impartially, a specific criterion of good governance has been designed as a tool effector in the national action plans of both developed and developing states. An accompaniment of good governance with socioeconomic sector in Pakistan has been distinguished as a critical phenomenon to the development process and to the effectiveness of development assistance. Because the issues of good governance are responsive to the present and future socioeconomic needs and developments, an insurance towards the condition of good
\end{abstract}


governance urges major donors and international financial institutions to spread investment over socioeconomic challenges and reforms in Pakistan. Hence strategic planning and management highlighted with quality and standards reinvigorate the practice of good governance through assuring socioeconomic development as a reality and fortune of the nation.

Keywords: Multilayered stratagem, governing hierarchy, accountability, transparency, rule of law and mass participation, Strategic planning, democratic system, balance of power, action plans, reforms, quality and standard, sustainability, assistance, investment

\section{Introduction}

Socioeconomic development is a congenital bulge over human civilization. That initiated as an indispensable instinct with the evolution of Man to proceed ahead towards the Byzantine philosophy of total satisfaction. As a result, its optimum level always exists in distinct future. Similarly, the notion of good governance serves as a designed infrastructure to reinvigorate socioeconomic quantum of development. In this perspective, good governance and socioeconomic development both are proportional to each other. Concept of socioeconomic development is measured with the most integral issues of human life and human values in a nutshell of specific indicators such as Gross Domestic Product (GDP), life expectancy, literacy, employment and etc. while governance is a broad and multidimensional term, designed as a key indicator of socioeconomic development by national and global entities of power. Thus, good governance is a gateway to open the equal opportunities of education, health, employment, transportation, food and shelter, and communication.

A variety of nation states confront gigantic challenges of good governance to establish a sustainable system of prosperity assurance. That could endeavor socioeconomic harmony and political stability at national and international levels. Considerably, this ideology has direct contribution in a splendid future of developing countries like Pakistan. The established system of multi priorities, designed under the web of good governance can galvanize Pakistan into a resonant and intensified development. Satisfactory governance exhilarates the credo of welfare state. Aspiration of converting a state into a welfare cloak would be originated through a redefined managerial approach of good governance. Political government strengthens institutional dominance, its preeminence over personalities or pressure groups, constitutional supremacy in critical issues, and the very goals of national cohesion as a whole. Good governance ascertains writ of the government. As the result, judiciary, legislature, and other governmental institutions perform their sufficient role in the enhancement of socioeconomic development. A well-defined realm of balance of powers directly affects the efficiency of government and nongovernmental organizations. That helps to manage the local, provisional and national level affairs and persuades responsible institutions to keep a vigilant eye over each other. 


\section{Purpose of the Study}

Author's foremost intention is to identify the most required efficacious tools of good governance. Accordingly, to what extent the key mechanism of good governance can be practiced in Pakistan in the course of socioeconomic development. The purpose of the study is multifold. Firstly it proposes to review the existing conditions of good governance in Pakistan; secondly, it propounds to pertain the standard structure of good governance over governing policies in Pakistan to draw a path towards socioeconomic development. Purpose of the study can further be evaluated as under:

- To investigate the direct relationship between good governance and socioeconomic development in the perspective of Pakistan.

- To examine the institutional writ and priorities in managing the governance issues.

- To estimate the role of political stability and its interference in the socioeconomic growth.

- To inquire the ratio of the rule of law, transparency, and accountability in the governmental and nongovernmental organizational behavior.

- To assess the aid criterion being consumed for good governance in Pakistan

\section{Research Methodology}

Good governance is to 'deliver' the development. However the task of good governance emerged as more challenging to the researchers, policy makers, academicians, intellectuals and concerned officials over a question of 'what to deliver' or 'how to deliver' in good governance. In this perspective, an empirical research has been applied over an enormous capacity of good governance in search of Flocabulary of sustainable socioeconomic development goals. Empirical evidence has been analyzed quantitatively. Combination of primary and secondary sources is set forth to grip the prescribed topic of good governance including official statements, and documents of international organizations. Clarity about various aspect of the topic has been attained through assistance depends on the official reports of United Nations Development Program (UNDP) and Pakistan Institute of Legislative Development and Transparency (PILDAT).

Moreover, the base of the findings depends on the following factual dimensions:

1. There is a direct relationship between good governance and socioeconomic development.

2. How elements of good governance such as transparency, accountability and rule of law strategically perform their roles for expected criterion of development.

3. What and how a sufficient financial plan for the projects of good governance assures development.

This research will examine the issues of good governance in Pakistan with respect to its prerequisite exertion in the country. The vacuum which has been created as a result of its negligence will be investigated by pondering over an action research in the field of good governance. Furthermore, this research results in four integrated ways instigating the current 
data analysis, significance of the study, method of action research and proper action plan.

\section{Literature Review}

The concept of "governance" is primordial in its nature and necessity. However, it delivers a variety of denotations with respect to different ages and multifarious civilizations. Review of literature has been designed to evaluate the very core concept of good governance and its relationship with the criterion of development. The need of socioeconomic development has been passed through a transitional periods of economic growth and social change. Jaffee (1998) has pondered over the necessity of socioeconomic development referring "to the ability to produce an adequate and growing supply of goods and services productivity and efficiently, to accumulate capital and to distribute the fruits of production in a relatively equitable manner. The gap between rich and poor, developed and underdeveloped, or first or third world nations reflects variations in the socioeconomic capacities." Agenda of socioeconomic development has been exercised through a systematic action planes of good governance. Governance is one of multifaceted practice implemented by formal or informal institutions in the management of national resources. In this perspective, the "quality of governance is thus determined the impact of this exercise of power on the quality of life enjoyed by its citizens."(Huther, 1894). United Nations Development Program further emphasized over the critical elements of socioeconomic development like elimination of poverty, creating jobs, protecting environment "to develop the capacities of good governance." (UNDP, 1997).

Moreover, theory and practice of good governance both have ultimate influences over socioeconomic development. International agencies such as United Nation Development Bank (UNDP), the World Bank, Organization for Economic Co-Operation and Development (OECD), Development Assistance Committee (DAC) and others define governance as the exercise of authority or power in order to manage a country's economic, political and administrative affairs. In this regard, the general definition of governance is of some assistance, indicating that governance is a synonym for government, or "the act or process of governing, specifically authoritative direction and control" (Webster, 1986). This interpretation specifically focuses on the effectiveness of the executive branch of government. The term 'governance' 'derives from the Greek 'Kybenan' respectively (the same Greek roots from which 'Cybernetics is derived) the process of governance is a process whereby an organization or society steers itself, and the dynamics of communication and control are central to the process" (Steven, 1992).

On the contrary, the British Council proclaimed governance "involves interaction between the formal institutions and those in civil society. Governance refers to a process whereby elements in society wield power, authority and influence and enact policies and decisions concerning public life" (National Party of South Africa, 1994). Similarly, the idea of good governance, with reference to the developing countries is epitomized by predictable, open and enlightened policy-making. In fact, Poor governance is characterized by arbitrary policy making, unaccountable bureaucracies, unenforced or unjust legal systems, the abuse of executive power, a civil society unengaged in public life, and widespread corruption. In this 
regard, good governance is actually "the manner in which power is exercised in the management of a country's economic and social resources for development" (World Bank, 1992). It cites four dimensions of governance which are: public sector management, accountability, and legal framework for information, transparency and development. In this perspective, sound development management is critical in ensuring adequate returns and efficacy of the programs and projects. The underlying objectives of international organizations help developing countries reduce poverty and promoting sustainable development growth.

Recently a concept of good governance is being focused all over the globe and is being used as a key indicator of the overall health of a country. According to Besancon (2003), 'Good governance is a result of effective performance and efficient working of the state machinery'. Furthermore, Grindle (2004) emphasized that the concept of governance is not so simple or straightforward to be linked with development. Basic agenda of Good Governance is to work for poverty reduction, countering corruption and other factors that are a hurdle in development.

In the words of Council of Rome, agenda of good governance has been explored as integral part of socioeconomic development it emphasized, good governance is "to denote the command mechanism of a social system and its actions that endeavor to provide security, prosperity, coherence, order and continuity to the system" (Schneider, 1991). Number of practitioners ponder over Scandinavian countries a remarkable example of a well-structured good governance at present time. Good governance most generally refers to a list of admirable characteristics of how government ought to be carried out "Sweden or Denmark on a good day, perhaps," as Andrews (2008) has written in a proclamation of societies with the satisfactory practice of good governance.

Modern states have chronologically chosen the elevating idea of good governance as a platform for political and socioeconomic development. It has become a nucleus for the new development approaches. The focus on good governance became a subject of consideration after 1980s; when the national and international agencies emphasized over aid, funds, and international assistance for developing countries (Killick, 1989). Furthermore, Grindle (2010) proclaimed that the notions to interrelate good governance with the development came from sixteen or seventeen century Europe to twentieth century America and to late twentieth century developing states. He further stated "academic literature and development discourse more generally flourished with discussions of the role of institutions in development and the positive contributions that states must make if market economies and democracies are to work effectively" (Grindle, 2010).

Although, number of developing countries in the twenty first century have realized the present challenge of good governance; that is severely affected by menace of corruption, poverty and unjustified distribution of wealth, penetrating into the roots of governance system. As the result, emphasis over more democratic regimes, role of citizens, electoral process, and civil organizations like media, political parties and pressure groups is prerequisite to pave the way for result-oriented good governance. Notably, Pakistan has been 
under the same whirlwind considering the rubric of good governance a confrontation for socioeconomic development.

\section{Discussion: Good Governance in Pakistan: A Critical Analysis}

Good governance is subjected as an intellectual interest of the state and the civil society in Pakistan. Terminology of good governance has been applied as a fig-leaf by democratic institutions for resolving the menace of bad governance in Pakistan. However, Good governance in Pakistan is synonymous to a cloak without an entity. Though the slogan of good governance has been raised high, the present practice of good governance lacks maturity and sustainability of the existing system. As the result, ground realities declare almost minimum realization in practice of the good governance for socioeconomic development. Putting off the acceptable management and action plans with courageous efforts cause to bring the homeland at the edge of 'do or die' dilemma. Neither the government officials nor the civil organizations confabulate with total determination and consideration for the serious issues of governance. Implementation of good governance goes languorous as compare to expected margin of development.

Pakistan is a multiethnic country with a variety of cultures within the isogloss of four provinces, Islamic sects, ethnic groups, urban-rural divisions, tribal areas and administrative units like Gilgit Baltistan and with a paradigm of civil- military bureaucracy that are main determinants of governance and development. Besides, the Contemporary homeland is beset by terrorism, sectarian violence, religious extremism, and critical geo politics faced by neighboring countries. Meanwhile, the hidden forces of disintegration and political instability automatically join the obvious problem of governance to react awfully towards socioeconomic development in the country. Similarly, a pile huge of ground rationales instantaneously redounds the socioeconomic amelioration in the republic state of Pakistan through political instability, political or bureaucratic unjust, extensive use of their powers, and abrupt consensus in the process of policy making. In the same way, inauspicious political leadership has shaken the roots of good governance too. As a result, already existed socioeconomic backwardness can hardly be vanquished. Notably, cyclone of dissatisfaction with the system disturbs the socioeconomic structure of Pakistani community, which is already limbering slowly. Hence, it immediately requires the issues of governance to have been commuted into rather severe challenges to be managed sufficiently. Because it presents a mass articulation of civil life of Pakistani citizens, goals behind a strong mechanism of good governance are to facilitate the nation with a better standards of living and uplifting economy. By setting the meaningful goals, socioeconomic development surely can prevail on a large level of civil sectors.

In the case study of Pakistan, issues of governance are to be overlooked with the perspective of state policies and the gradual development of state institutions with respect to their roles in enhancing good governance in the country. There have been several governmental and nongovernmental or many civil and militant factors involved in fluctuating the streamlined parameters of good governance in the country. Pakistan has a complex political chronology. Good governance in Pakistan can chronologically be evaluated from its independence to the 
recent years of enlightenment. It has passed through a variety of socioeconomic and political tenure in Pakistan. It can be listed as under:

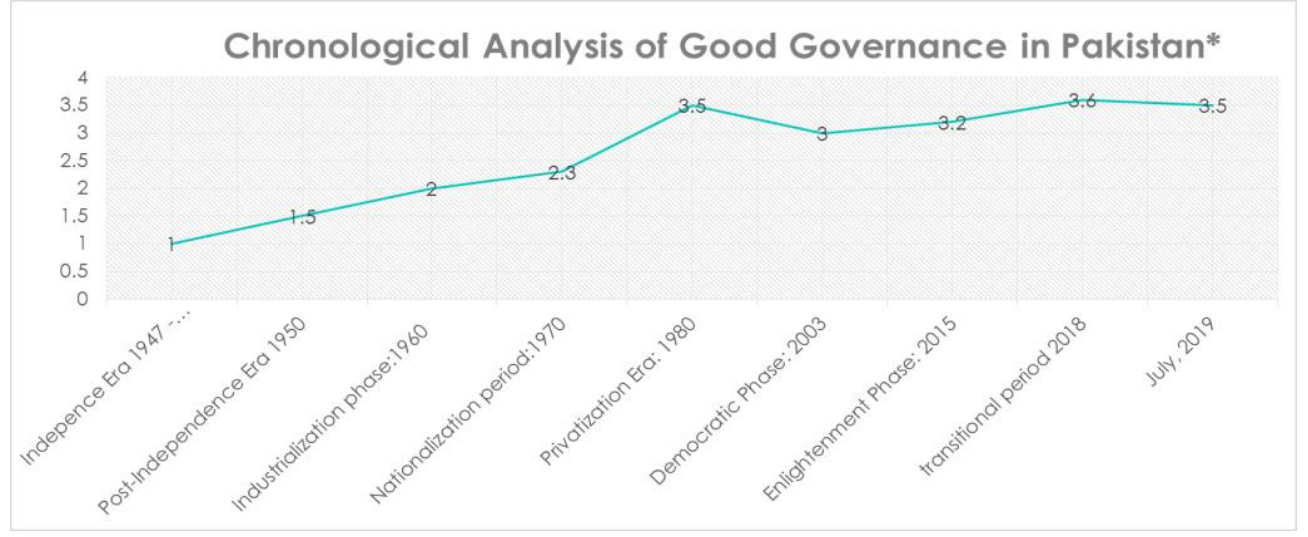

Figure 1. Good Governance in Pakistan from 1947 to 2019

Historical perspective of the decay of good governance in Pakistan manifests challenging tasks of the management and governance. Since the existence of Pakistan, there has been a continuous dilapidation of good governance in almost all socioeconomic and political institutions. This can be seen in gradual colloquium of the stagnant level of socioeconomic development. Pakistan availed settled structure of civil service, military bureaucracy and judiciary at the time of its birth but new legislature couldn't deliver up to the mark to maintain governance especially in public institutions. As the result, a clear diversion was generated within the state in favor of few ones. Independence era has been undoubtedly marked with innumerable socioeconomic disasters that marks the governance in deficit category. Corruption was spread in a form of liberal grant of lands. Role of feudal became suspicious in a matter of governance at very local level. Similarly, irregularities were deployed in refugees influx and settlement scams. Thus, inherited institutions failed to continue the development and playing its significant role in socioeconomic development.

Furthermore, post-independence era bring indispensable challenges of governance in almost every institutional development. In 60s era when huge industries emerged and became a source of economic growth in Pakistan, a political change and financial program was launched to work upon good governance actively. This time period of industrialization in Pakistan came during the regime of Ayub Khan (ex-president 1958-1969) up to 1970. He gave Basic Democracy System and practiced governance through decentralization. However, his regime has been evaluated with unjustified distribution of government money into many schemes. That facilitated industrialists and bureaucrats. They used to support the interests of each other's. A ward of permits and bank loans were given on a political consideration. This era was engulfed with the corruption at national level and continued till the dismemberment of East Pakistan in 1971.

Wave of nationalization was promoted by Zulfikar Ali Bhutto (1971-1977) to handle the governance in all sectors. He nationalize innumerable industries, banks and institutions. This change faced serious problems of planning adjustment which were not given proper heed due to non-political actors in using state authority. Later on, the political tenure of Zia-ul-Haq 
(1977-1988) Local Bodies System was practice to prevail democracy and good governance. On the other hand, his policy of denationalization boosted private sector in Pakistan. The source behind emerging conditions in economic growth and good governance was easy-way infiltration of money in Pakistan through Islamization, or Russian war. The notion of denationalization gradually enhanced the agenda of good governance. General Zia handed over many nationalized industries to individual owners.

During 1980s to1990s era, privatization of state and commercial enterprises became common phenomenon. Private sector enhanced economy as well as took the limited governance issues in its own hand due to deteriorating outcomes of governmental policies for good governance. Privatization was used as a strategic tool to improve the efficiency of governance. It brings about revolutionary policies of good governance that have been implemented in segments of private sectors only. To some extent, national policy of deregulation and privatization gave rise to corruption in promoting the factor of self-interest of the officials related to political and nonpolitical offices, taking part in privatization directly or indirectly.

Later on, coming democratic phase in Pakistan became a source of inadequate dealing with governance issues because of irregular tenure of political parties and fluctuation in public policies. PMLN and PPP both convicted and delivered differently to enforce policies for good governance by focusing on privatization and other one on nationalization. Abrupt policy transitions could not let the good governance program uplift properly.so four elected governments within a span of ten years from1988 to 1999 couldn't cope with governance issues. Metaphorically, natural outcome of privatization gradually increased the economic growth, without maintaining good governance due to absence of transparency and accountability. Self-centered policies and practices have been exercised deeply to favor the elite class in political and nonpolitical institutions and to deprive the general public from resources and their legitimate rights of availing good governance in the country. With the same deprivation, Pakistan steps into twenty first century.

Comparatively, initial decade of Pervez Musharraf's government tried to trickle down the effect of economic growth over all in the county. For, he inaugurated a National Commission on Government Reforms (NCGR) and established National Accountability Bureau (NAB). However, credibility of NAB has been questioned because military and judiciary are not hauled up in the accountability. Similarly his devolution of power plan (DOPP) for decentralization was imposed to improve governance but caused a major gust to the image and strong hold of civil service in Pakistan. Offices of Commissioners, Deputy Commissioners (DC) and Assistant Commissioners (AC) were abolished and were transformed to the elected Nazims.

The new democratic phase was expected to bring new hope to the mechanism of good governance. For this the elected government of Pakistan Peoples' Party Parliamentarian (PPPP) in 2008, PML-N (Pakistan Muslim League N) in 2013 tried took different initiatives. Asif Ali Zerdari (ex-President 2008-2013) passed eighteenth amendment that abolishing the president's power to unilaterally dissolve the Parliament, empowers provisional governments to deal with their several governing issues on priority bases. Number of military operations 
were launched against terrorism in Pakistan to bring peace, federal and provisional governments signed the agreement of provinces' financial autonomy in NFC Awards (National Finance Commission Awards) that increase the provincial shares. Nonetheless, number of issues related to Internally Displaced Persons (IDPs) crises seem not to be manage satisfactorily. Similarly, there was enough international financial aid from other states and agencies to be received to manage the governance issues rapidly, however, these crises still seems to be unresolved. On the other hand, total external debt and liabilities have increased to 92 billion dollars by 2018 that was 61 billion dollars in 2013 (CEIC, 2019). In these circumstances it obviously seems difficult to exercise the notion of good governance with its full velocity.

Furthermore, Pakistan Tehreek-e-Insaaf (PTI) has been elected in the span of third continues tenure of democratic government in the year of 2018. Slow space good governance of PMLN tenure has got to seem stagnant after July 2018 due to a rapid change of public policies, inflation, and deduction in the budget of PAC (Public Account Committee). Undoubtedly, it seems to diminish the good governance mechanism with the least financial assistance. On the other hand, the prominent slogan of corruption free society seems at a snail's pace in recovering the public money to maintain socioeconomic growth of the country. Analytically, the regime of initial ten months cannot be ample guide for governance and reputation, however initial policies related to basic social and economic needs of people, rapid economic growth and institutional reforms to deliver the best of their resources are the tactical tools to judge the rest of performance of the government. In this regard, recent facts seem hard nut to crack in favor of consistent and rapid uplift of good governance. Number of initiative still seem to fluctuate the economy such as ties with foreign countries and IMF. Even though, an expected hope twinkles towards the betterment specially after new housing policy, preparation of construction of a dam, extemporary interference in bureaucracy, and local government reforms.

In the recent decade, continuity of democratic governments caused upward in corruption and deterioration of good governance. Housing and social development sectors have almost been collapsed due to unjust and corruption. All mentioned reasons have not let the good governance uplift in favor of socioeconomic development of Pakistani society. Forthwith, accomplishment of sustainable development goals is an enormous inclination for Pakistan. Though, Pakistan ranks 150 out of 189 countries in Human Development Index (HDI, 2015), and its progress is very slow as compare to other South Asian countries as mentioned in Human Development Report (UNDP, 2018), a responsible approach has been emerged in few back years to address the development goals by a rational policy making and an authentic planning of good governance in a well-mannered way. A list of seventeen international sustainable development goals has been applied contextually and prioritized way in all provinces and administrative units of Pakistan in recent years. The common purpose behind it, is to drag Pakistan into a new phase of good governance by 2030.

Though governance issues have been emphasized from the center, Political leadership of various provinces ponders over the strategy of good governance differently and deeply too. Each of them comparatively has a better goal line to cope with the issues of governance in 


\section{Macrothink}

their local assemblage. Pakistan Institute of Legislative Development and Transparency (PILDAT) has reported on quality of governance in Pakistan after the general election 2013 and 2018.

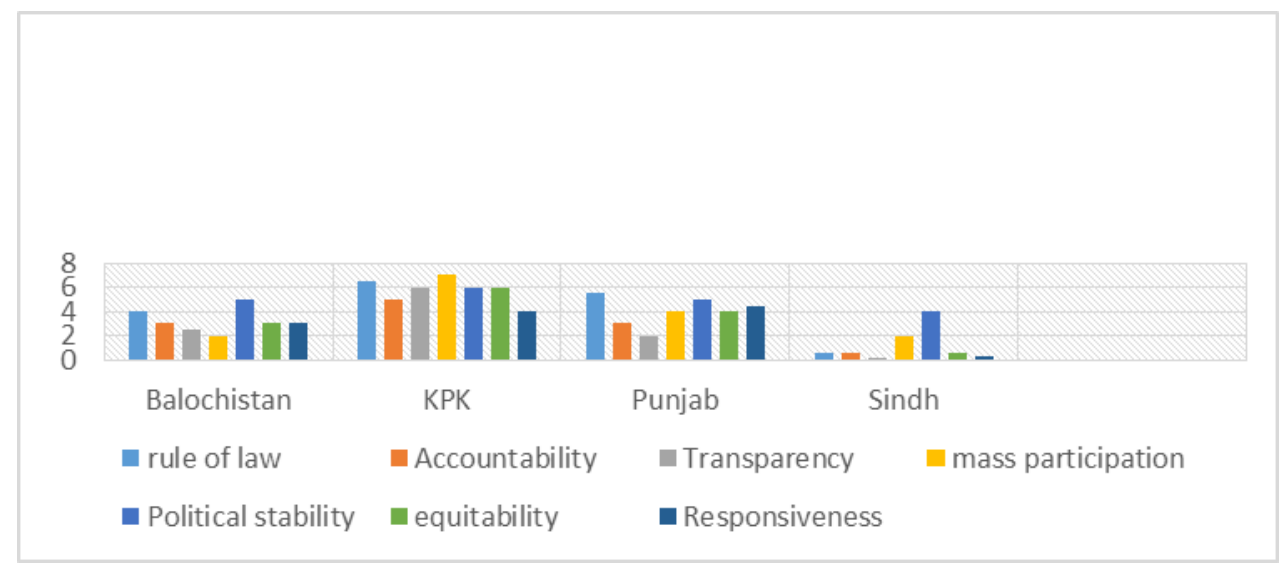

Figure 2. Achieved Dimensions of Good Governance (PILDAT, 2015-16)

With reference to PILDAT survey 2015-16, Government of Khyber Pakhtunkhwa (KPK) has appeared to have highest positive evaluation on 18 out of 28 Governance Indicators. The Government of Punjab, positively evaluated on 8 out of 28 Governance Indicators, and Government of Baluchistan and Sindh, both evaluated on only 2 out of 28 Governance Indicators (PILDAT, 2015).

Table 1. Quality of Good Governance (PILDAT, 2017)

\begin{tabular}{|c|c|c|c|l|l|}
\hline Year & Punjab & KPK & Sindh & Baluchistan & $\begin{array}{l}\text { Federal } \\
\text { governance }\end{array}$ \\
\hline $2015-2016$ & $65.5 \%$ & $63 \%$ & $59.7 \%$ & $65.5 \%$ & $51 \%$ \\
\hline
\end{tabular}

Prescribed chart highlights the growth of good governance in center as well as in provinces.

In recent years, different strategies have been applied to boost up the accountability, transparency and rule of law through high profile NAB cases and National Action Plan. According to PILDAT report "politicians disagreed on across-the-board accountability" that causes questioning over NAB transparent role to prevail accountability in the country (PILDAT, 2018). Recently, Punjab local government bill 2019 has been passed by Punjab Assembly, which is to be considered a game changer to implement good governance in Punjab through transfer of powers to the grassroots level. 


\section{Significance of the Study}

In the case study of Pakistan, notion of governance can be comprehended through eclecticism in the attainment of economic growth; that has been exerted by political rightist and political leftist contrarily. Most of the time, good governance is conceived by government in public sector emphasizing public authority in decision making. On the contrary, in leftist opinion, good governance is a source of elevating the apothegms of social equity, and protection of poor, woman and minorities. Indeed, Cross disciplinary approach of intellectuals generates a base for human development through a better governance which is to be implemented on practical grounds. Where political and economic streams are amalgamated for the task of result oriented governance highlighting the success factor in Pakistan.

Good governance explores a bright future and satisfactory present. It is a key element leading to socioeconomic elaboration. Significantly, good governance evaporates uncertainty risks to prevent a high contingency of cultural, financial and democratic failure. Implementation of policies about a modeled good governance not only assesses the satisfactory role of the state but invigilates domestic leadership to assure socioeconomic enlightenment. In this regard, good governance has become an integral part of development criteria.

In Pakistan, good governance is to be effectuated as a trans-actor through its multidimensional mechanism. It is tool engine to examine the development ratio by evaluating the practice and outcome of the indicators of good governance. Significance of the study is to enhance the multiplicity of good governance strongly through emphasizing over rule of law, accountability, transparency, equity, and mass participation. Law is enforced to ensure governance rules; accountability is focused to convey good governance efficiently; transparency is to bring validation in the governance system; mass participation is for ultimate mass satisfaction with the system and to come up to level of fairness; political stability is to enhance continuity of good governance and adjustment of international aid; similarly, public policy is undertaken for the sustainability of good governance. It is referred that the dimensions of good governance "participation, fairness, decency, efficiency, accountability, and transparency" are equally evocative (Hyden et al, 2004). Indeed, author's viewpoint to attribute the issues of good governance as a high settled infrastructure through the allocated priorities of good governance in the enhancement of development goals can solemnly handle the existing paradigms of good governance in Pakistan. That are evaluated by intended empirical research.

The transitions from traditional management of governing issues to the modern managerial outfits of governance in Pakistan yield a thorough observation to achieve development goals. Good governance has always been an attribution to sustainable socioeconomic development goals in Pakistan. It is utmost to comprehend the prevailing criterion of development through a well-structured good governance at local as well as at national level. Good governance has proclaimed the nature and necessitation of socioeconomic development. In this perspective, crises of development have four features in the scenario of Pakistan. These can urge the eclectic and resourceful approach towards mechanism of good governance. The most critical issues of development can be stated as under; 
- Economic growth is associated with poverty

- Rapid Urbanization Rate

- Rising debt and government expenditures on unproductive purposes

- Rapid erosion of natural resources (Hussain \& Hussain, 1993)

Indeed, a mature and standard web of good governance would lead the motherland towards attainment of development.

\section{Action Research}

Pakistan requires an innovative policy, action research and a development plan for gradually increased level of good governance. It is utmost to establish a strategic vision of good governance adhered to socioeconomic development. It is comprehended with an ultimate inquisitive tone about what is to be required; what is to be planned; what are expected upshots. Any governance endeavour has been achieved by a systematic overlapping of governance actors; it refers to state or government, civil society, and private sector. State is notified as a resource provider; civil society is contemplated as a participant through local government. While business sector sets a corporate governance. Credibility of good governance is inquired to be efficient and equitable. Where governance must facilitate marginal localities. Apprehension of good governance is broader than the government itself. Strategic approach of governance is innovative to govern the issues. It is directly related to socioeconomic development through action research. Hence, criterion of good governance is intimated to be exercised through its multifold practice.

Mechanism of good governance revolves around a multilayered nucleus folded by the basic ingredients of policy making such as, good governance (policy), dimensions of good governance, favorable conditions, sufficient budget or aid and finally as mentioned in figure 1 , outcomes or result orientation of entire involved governance. Authentic research has been designed to recommend the intellectuals and policy makers to redefine the policies of good governance on rational basis. Secondly, the proactive role of dimensions of good governance is to be technically utilized to achieve expected results. Earlier mentioned dimensions are interrelated clusters; the implementation of all dimensions together educes authenticity and promotion in governing operation. Next, a conglomeration of favorable conditions is delineated to pave the way for the enactment of good governance. Political stability, judicial freedom, fight against corruption, and democratic values pertain governance to be participatory, equitable, inclusive and responsive. Strength of decentralization measures dual purposes in development; first, it elevates democratic hybrid; secondly, it is remodeled as a distributor of wealth, provider of employment and products; that enhances the standard of living of general public.

Moreover, an adequate financial plan consists of allocation of appropriate budget and assistance would invigorate the infrastructure of planning. Good governance is a major aspect of development assistance. Modern advancement could be infixed properly through the exposure of good governance. International grant for governance and management has to be consumed artistically in the pursuit of ultimate goals of socioeconomic development. In this perspective, financial framework and efficient field work in accountability, transparency, and 
communication sector need adherence to the international standards. Similarly, efficiency and sustainability of good governance depend on the broad consensus and involvement of vulnerable voices heard in decision making over the allocation of development resources. In this regard, the following action research suggests certain targeted areas and critical planning to deliver the governance with suitable conditions. This action research leads policy makers towards expected results and feedback. The detail is given below:

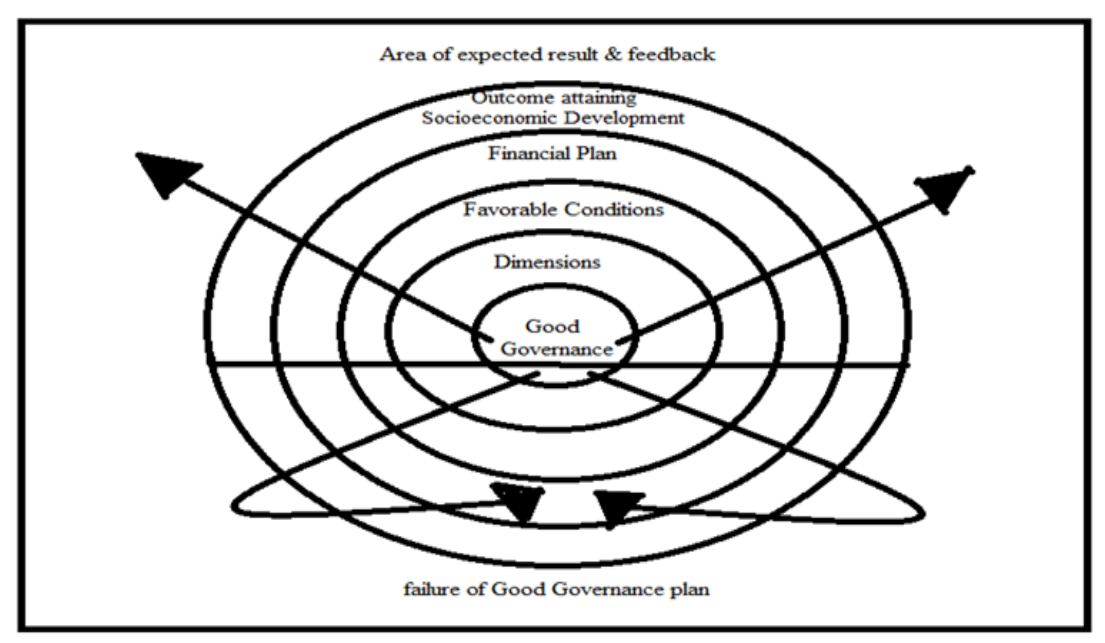

Figure 3. Mechanism of Good Governance

The inward and outward positions in figure 3 depict a variety of outcomes resulted by set patterns of good governance practices. Enlightened policies accomplishing a development target are shown by inward policies which are preceded by the outward positive effects in upper part of the diagram. On the contrary, a bottom part of the diagram reveals any undesirable feedback due to deficit in governance policies. As a result, there is immature estimation of governance and no sufficient socioeconomic development seen. This figure focuses on authentic action research and action plan.

\section{Action Plan}

Good governance is a spectrum to be examined in a response to bottom up theory. It can be widely categorized into certain levels of analysis in the study of good governance. This significant analysis notifies levels from bottom to top management. Therefore, hierarchy of power is to be settled in a web of administrative accountability and transparency. It provokes different administrative levels to practice team work with mutual contemplation of all government offices. These administrative levels communicate interpersonally as well as intra-personally. First, the criteria mentioned as individual levels describes personal values, motives and attitude of the officials. Next, institutional level depicts political and economic organizational structure; in the same way, regional level focuses on local government, provisional ministries and undertaken sectors for the sake of economic growth; then, national level is to highlight utmost governing consensus and distributing national resources accordingly; at the last, global level governance analysis is to be used comparatively to match 
the principles, infrastructure and policies of good governance. Secondly, it is considered to relate the state entity in world politics. Hence, it assists to maintain balance of power in a hierarchical way from top to bottom and to effectuate sufficient answerability in a bottom-up propositions. This action-oriented approach would design an authentic mechanism of good governance. A number of strategic tools and applications of governance can lead the entire government system into good governance mechanism. In this perspective, launching of 'anti-corruption' campaigns, rising the slogans of 'strict accountability', inquiry in development sector, investigation of resource management, allocation of resources and assets can revitalize the analytic levels of good governance for a splendid future of the state.

'Enlightened modal' of top priorities relating to the issues of good governance can vanish remonstrance faced by the nation. Governance would be knitted with the yarn of interest and priorities of each analytic level to sustain development goals. Consequences of good governance are highly settled through the governance priorities to not only avoid the degradation of the quality of governance but to highlight the integrity in the infrastructure of good governance. It expectedly leads towards the sustainable development goals (SDGs) and millennium development goals (MDGs). These priorities are based on the management of human needs. A result oriented governance always is to be focused on vicious cycle of human need from basic social and economic need to a need of the best standard of living. Thus it revolves from fundamental necessities to advance desiderata. Indeed, priorities of development agenda are set forth culturally, politically economically and socially in the infrastructure of good governance that can surly indicate an integral role of it for development.

\section{Further Recommendations}

There is need to apply a notion of good governance with more focus and continuity of action plans. Sufficient target oriented policies must be designed independently. In this perspective, the following directions will improve the dimensions of good governance:

1. Target oriented policies must be designed independently. There must be practicality of the policy to assure sufficient result.

2. It is utmost to experience the launching of an 'anti-corruption' campaigns throughout the country. It may be divided at regional and national level administration.

3. There is a need of rising the slogans of 'strict accountability' in all types of organizations; whether these offices directly or indirectly affect the governance issues of public.

4. It is obligatory to conduct a formal survey of inquiry in development sectors to estimate the present ratio of development in different fields. It will help to set the urgent goals.

5. Investigation of resource management must be exercised. There is direct relationship between governance and socioeconomic development of the country therefore resource management will assist the right sector to be given investment. 
6. It is prerequisite to assure the allocation of resources and assets constitutionally. The maximum projects must be initiated and completed according to the national and provisional constituency and their political needs.

7. There must be strengthened designing of 'Enlightened model' of top national or regional priorities relating to the issues of good governance. Priorities are required to be based on the management of human needs. That revolves from fundamental necessities to advance desiderata. It surely include basic human needs, social and economic security, education, employment and a better standard of living.

8. Integral approach and bottom-up tactics must be exercised in a vast range of hierarchy of power in government institutions.

9. Institutional cooperation and balance of power must be given priority and respect. It will continuously promote over all work-effect without administrative stoppage.

10. In Pakistan, there is need to establish an approach of comparative study with developing as well as developed countries to make governance infrastructure more flexible and applicable.

\section{Conclusion}

Good governance is a new tendency for development discourse discussed in Pakistan in recent years. It is multidimensional intellection to cope with innumerable problems of governance simultaneously at local as well as at national level. Realistically, Pakistan has been facing nonstop challenges in almost every field of life especially after the regime of new democratic government in 2018. The most critical and alarming conditions are being observed in economic issues. Increasing debt, devaluation of rupees as compare to dollar, inflation, money laundering and white collar corruption have broken the backbone of infrastructure of good governance in public organizations. Similarly rapidly decrease in public accounts sucks the mature approach of socioeconomic development in the country. Though it is sufficiently comprehended that good governance is key to conflict management, governance management and resource or revenue management in all over public sectors, the issues of jeopardizing the newly born mechanism of governance must be considered seriously too to continue the milieu of good governance. It can surely seize to advantage the particular institutions and families. Secondly, a large part of international aid has also been watched out for transparency in allocating it on fair basis. The non-state actors which surely must not been prioritized over state actors and democratic writ of the state to promote equal socioeconomic development for all social and political stratification. In this regard, political economy of the country must be strengthened. There is tremendous need to design a flexible policy making that would be beneficial for all public sectors and utilize funds on root level governance. In fact, in-depth action research, strategic action plan and sufficient field work is indispensable phenomenon that must be initiated in all socioeconomic public sectors for the sake of good governance. It is a hope to lead Pakistan towards immense economic growth.

Good governance is an umbrella term denoting the cycle of economic growth and sufficient funds for governance and impact of good governance for socioeconomic development. Good governance results through structural underpinning of public policies, public assets and public authority. Success factor for good governance depends on excellent planning, 
sufficient financial budget and accountable team, before actual enforcement of policies. Most importantly is the vigilant eye over targeted areas in public sectors. The word Public must be emphasized as a focal point to apply good governance policies. Because, an action research and action plan both guarantee excellence in governance through strategic implementation of the public policies. There is need to carry top-down approach to prevail accountability in hierarchy of power. Good governance can be saturated in the system when highly officials are professionally involved to drag it on right track. In fact, convincing the true spirit of good governance has an equal share of the support of judiciary, structural bureaucracy, civil society, economic and political realms, that assures over all socioeconomic development in the country.

Determined insertion of the principles of good governance has been emerged in national attitude and national policies of Pakistan. It would highlight the society into a community development. Consistent application of good governance surely help to build a national character of public institutions and reinforces sustainability of moderate standard of living by focusing bottom-up planning with top-down accountability. Menace of corruption, poverty insecurity, and illiteracy are strategically vanquished through good governance mechanism. Multiple purposefulness of good governance policies has endurance to not only invigorate present perspective of good governance but to confront future predicaments reinforcing socioeconomic development. It ensures reincarnation of national infrastructure embarking a splendid future of Pakistan. Hence, good governance can turn Pakistan into social welfare state which has been a democratic slogan of progress and prosperity since its existence.

\section{References}

Andrews, M. (2008). Are Swedish Models of Effective Government Suitable in the Development Domain, Do We Need a Theory of Government before We Measure Government Effectiveness? Manuscript, Kennedy School of Government.

Besancon, M. (2003). Good Governance Rankings: The Art of Measurement. World Peace Foundation-WPF Program on Intrastate Conflict and Conflict Resolution, John F. Kennedy School of Government, Harvard University Cambridge, Massachusetts.

CEIC, 2019. Pakistan External Debt, 2006-2019

https://www.ceicdata.com/en/indicator/pakistan/external-debt

Grindle, M. S. (2004). Good Enough Governance: Poverty Reduction and Reform in Developing Countries. An International Journal of Policy, Administration, and Institutions, 17(4), 525-548. https://doi.org/10.1111/j.0952-1895.2004.00256.x

Grindle, M. (2010). Faculty Research Working Paper Series, 'Good Governance: The Inflation of an Idea' June; RWP 10-023. 3.

Human Development Index (2015). http://www.hdr.undp.org/en.

Hussain, M., \& Hussain, A. (1993). Pakistan Problems of Governance, Vanguard books Pvt LID. www.akmalhussain.net/publish 
Huther, J., \& Shah, A. (1894). Applying a Simple Measure of Good Governance. Policy Research Working Paper.

Hyden, G., Court, J., \& Mease, K. (2004). Making Sense of Governance: Empirical Evidence from Sixteen Countries. Boulder, CO: Lynne Rienner.

Jafee, D. (1998). Levels of Socioeconomic Development Theory. Greenwood Publishing Group, 3. Print.

Killick, T. (1989). A Reaction Too Far: Economic Theory and the Role of the State in Developing Countries. Overseas Development Institute, London.

National Party, (South Africa). (1994). Governance Barometer: Policy guidelines for good governance. Cape town Publishers, Dept. of strategy, Federal council. www.worldcat.org

PILDAT (2015). 'Governance Poll’ 2015. www.pildat.org

PILDAT (2017). Annual Report: 2016-2017.

https://pildat.org/wpcontent/uploads/2018/05/Anual_Report2016-2017.pdf

PILDAT (2018). Annual Report: 2017-2018.

https://pildat.org/wp-content/uploads/2019/04/Anual-Report-2017-2018.pdf

Rosenau, J. N. (1991). Along the Domestic Foreign Frontier: Exploring Governance in the Turbulent World' Cambridge University Press. Print (Alexander King \& Bertrand Schneider, The First Global revolution; A Report of the Council of Rome, New York Pantheon Books, pg. 181. Print)

Steven, A. R. (1992). Governing in an Information Society. Montreal institute for Research on Public Policy, 21.

UNDP (1997). Policy Document, governance for sustainable Human development. http://magnet.undp.org/policy/

UNDP (2018). Human Development in Pakistan.

http://www.pk.undp.org/content/pakistan/en/home/blog/2018/human-development-in-pakista n.html

Webster's Third New International Dictionary. (1986). www.dictionary.com

World Bank. Report. (1992). Governance and Development. http://documents.worldbank.org/curated/en/

\section{Copyright Disclaimer}

Copyright for this article is retained by the author(s), with first publication rights granted to the journal.

This is an open-access article distributed under the terms and conditions of the Creative Commons Attribution license (http://creativecommons.org/licenses/by/4.0/). 